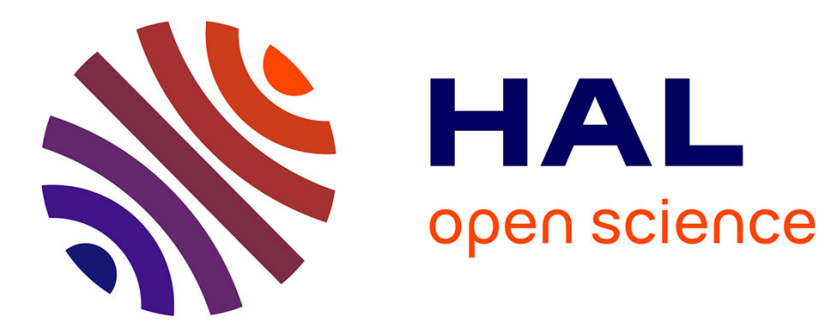

\title{
A first french assessment of population exposure to tetrachloroethylene from small dry cleaning facilities
}

Laura Chiappini, Laure Delery, Eva Leoz-Garziandia, Bruno Brouard, Yoann Fagault

\section{- To cite this version:}

Laura Chiappini, Laure Delery, Eva Leoz-Garziandia, Bruno Brouard, Yoann Fagault. A first french assessment of population exposure to tetrachloroethylene from small dry cleaning facilities. Indoor Air, 2009, 19 (3), pp.226-233. 10.1111/j.1600-0668.2009.00585.x . ineris-00961934

\section{HAL Id: ineris-00961934}

https://hal-ineris.archives-ouvertes.fr/ineris-00961934

Submitted on 20 Mar 2014

HAL is a multi-disciplinary open access archive for the deposit and dissemination of scientific research documents, whether they are published or not. The documents may come from teaching and research institutions in France or abroad, or from public or private research centers.
L'archive ouverte pluridisciplinaire HAL, est destinée au dépôt et à la diffusion de documents scientifiques de niveau recherche, publiés ou non, émanant des établissements d'enseignement et de recherche français ou étrangers, des laboratoires publics ou privés. 


\title{
A first French assessment of population exposure to tetrachloroethylene from small dry cleaning facilities
}

\section{Laura Chiappini*, Laure Delery, Eva Leoz, Bruno Brouard, Yoann Fagault}

INERIS (Institut National de l'Environnement Industriel et des Risques)

Parc technologique Alata

BP2 F-60550 Verneuil-en-Halatte

Fax 0033344556302

*Author to whom correspondance should be addressed : laura.chiappini@ineris.fr

\begin{abstract}
Used as a solvent in the dry cleaning industry, tetrachloroethylene can be a pollutant of residential indoor air, which can cause long term harmful exposures because of its neurotoxicity and probable carcinogenicity.

In France, dry-cleaning facilities are integrated in urban environments (shopping malls, residential buildings) and can contribute to tetrachloroethylene exposure for customers and residents.

This exploratory work presents the results from five studies carried out in one shopping mall and four residential buildings housing a dry cleaning facility. These studies involved dry cleaning machines fitted with a Carbon Adsorber (CA) and unfitted, with or without Air Exhaust System (AES).

Samples were collected in the cleaning facilities and in the apartments located above with passive samplers allowing measurement of time-integrated concentrations on a 7 days sampling period.

It has obviously shown the degradation of indoor air quality in these environments and underlined the contributing role of the machine technology and ventilation system on the amount of released tetrachloroethylene in the indoor air.

To temper these results, it must be pointed out that some parameters (building insulation, amount of solvent used...) which would influence tetrachloroethylene fugitive release have not been quantified and should be looked at in further studies.
\end{abstract}

Key words: tetrachloroethylene, dry cleaning facilities, indoor air quality, passive sampling, population exposure.

Practical implication: In France, dry-cleaning facilities are frequently integrated in urban environments (large shopping malls or residential buildings) and can significantly contribute to tetrachloroethylene population exposure. The amount of fugitive releases in these environments depends on several parameters such as the dry cleaning machine technology (fitted or unfitted with a carbon adsorber) and the ventilation (air exhaust system). In order to reduce tetrachloroethylene exposure in residential buildings and other indoor environments with on site dry cleaners, carbon adsober unequipped machine should be replaced by newer technology and dry cleaners should be equipped with mechanical air exhaust systems.

\section{Introduction}

Tetrachloroethylene $\left(\mathrm{C}_{2} \mathrm{Cl}_{4}\right)$, also called perchloroethylene (PCE), is a polychlorinated solvent abundantly used in French dry cleaning facilities (Poirot et al., 2007). It has been identified as an hazardous urban air pollutant causing acute, chronic and potential carcinogenic health effects by the U.S. Environmental Protection Agency (USEPA, 2000). Because of its high volatility, 
inhalation is the main human route of exposure to PCE. An international target indoor air concentration of tetrachloroethylene has not been set yet. The New York State Department of Health (NYSDOH) has developed a health-based guideline of $100 \mu \mathrm{g} \mathrm{m}^{-3}$ for chronic exposure (15 ppb) (NYSDOH, 1997). In Germany the value of $5 \mu \mathrm{g} \mathrm{m}^{-3}$ has been proposed for chronic exposure (Schleibinger et al., 2003). In France, there were close to 7500 dry cleaning establishments in 2002 operating 1 to 2 machines. Because of the lack of national data, a complete inventory of the French dry cleaning machine number and type cannot be done. However, it can be assumed that only a few percent of these machines are equipped with a carbon adsorber, CA, to capture PCE vapours, and also a few percent of the dry cleaners are equipped with an Air Exhaust System, AES, (Déléry, 2007). Moreover, in France, dry-cleaning facilities are very frequently located in environments such as large shopping malls or residential buildings. Thus, it seems reasonable to suppose that dry cleaning facilities can significantly contribute to PCE exposure for supermarket customers and building residents. Indeed, when the mean indoor PCE concentration measured in France is $7.4 \mu \mathrm{g} \mathrm{m}^{-3}$ (Observatory on Indoor Air Quality (OQAI), 2006), PCE levels in residential air can be much higher and range from a few hundred to thousands of microgram per cubic meters (Altmann et al., 1995; Garetano and Gochfeld, 2000; Schreiber et al., 2002).

Because dry-cleaning can significantly contribute to tetrachloroethylene exposure of neighbourhoods, the aim of this work was to determine indoor air levels in typical French environments housing a dry cleaning facility. Measurements were carried out in one shopping mall and 4 residential buildings with on-site dry cleaners located in the basement floor.

The influence of the dry cleaners technology (equipped or unequipped with a CA) and shop ventilation was also assessed during this study.

\section{Study design}

Indoor air PCE levels from four residential buildings and one shopping mall with on-site dry cleaners were determined between 2002 and 2007. The sites were chosen to study the exposition of population to tetrachloroethylene in the two main French environment in which dry cleaning facilities are settled: residential buildings and shopping mall.

Therefore, two preliminary sampling campaigns using canisters (10 hours sampling period) were conducted in a supermarket (study 1) and in a residential building (study 2) in 2002.

An other criterion to chose the sampling sites was the machine technology: in each case, the machine were closed with refrigeration cooling and were equipped or unequipped with a Carbon Adsorber (CA).

Thus, for the remaining studies (studies 3, 4 and 5), led between 2005 and 2007, sampling campaigns were performed in three different residential buildings with on-site dry cleaners equipped (study 5) and unequipped (studies 3 and 4) with a CA. During these campaigns, 7 days time integrated samples were collected using passive samplers in order to obtain more reliable estimation of residents exposure.

The sites description as well as four important parameters (machine technology, dry cleaning facility ventilation, shop activity and temperatures in the shop and the apartments, when available) influencing the amount of fugitive PCE concentrations in indoor air are reported in Table 1. In each case, only one dry cleaner was in function in the facility. Studies 1 and 5 concerned dry cleaners using CA equipped machines. Air exhaust system was only present in study 5 . In study 1 , samples were taken in 10 different locations of a supermarket in a shopping centre housing a dry cleaning facility.

Studies 2, 3 and 4 concerned dry cleaners using unequipped CA machines. The dry cleaning activity was high in study 1 (11 loads/day), normal in studies 3, 4 and 5 (6-8 loads/day), low in study 2 (3 loads/day). No measurement was performed in the dry cleaning shop of study 1 . 
Sampling was only performed in the staircase of the residential building in study 2 while sampling in study 3, 4 and 5 was performed in both staircase and apartments.

No background site was chosen to give information on background PCE levels since it has been assumed that the dry cleaner was the major source of PCE. In fact, it must be pointed out that, for each chosen dry cleaning facility, no other dry cleaner, closed enough to affect PCE measured level, was present in the surrounding area. Moreover, all of them were located in residential area, far from potential industrial influence. Mean PCE concentrations measured in the dwellings of 567 French families between 2003 and 2005 (Observatory on Indoor Air Quality (OQAI), 2006) will be taken as a reference to compare the studies.

\section{Air monitoring and sample analysis}

Sampling devices and period for each study are shown in Table 2. Studies 1 and 2 were carried out with $6 \mathrm{~L}$ stainless steal canisters while studies 3, 4 and 5 were carried out with passive samplers. For each studies, all the samples were collected at the same time.

\section{Sampling equipment and conditioning}

Electropolished stainless steel canisters were purchased from Resteck (Silocan ${ }^{\mathrm{TM}}$ ). Cleaning was performed by repetitive evacuation and refilling with humidified zero air at $100{ }^{\circ} \mathrm{C}$. The efficiency of the cleaning procedure was verified by GC analysis. A full description of the adopted procedure can be found in Castellnou et al., 1997. Passive tubes were conditioned by purging with ultra-high-purity helium at $50 \mathrm{~mL} \mathrm{~min}^{-1}$ while heated at $350{ }^{\circ} \mathrm{C}$ for at least 8 hours. After conditioning, the sorbent tubes were capped with stainless steel Swagelock nuts.

\section{Sampling and analysis with canisters}

Canisters were fitted with Veriflow controller (Restek inc) maintaining a constant flow (about $10 \mathrm{~mL} \mathrm{~min}^{-1}$ ) into the canister over the sampling period of 10 hours.

Canisters were analysed by transferring an aliquot (2 litres) of the collected air onto a Perkin Elmer desorption tube filled with $150 \mathrm{mg}$ of carbotrap B and cooled down to $-10^{\circ} \mathrm{C}$. Details of the transfer apparatus were described by Castellnou et al., 1997.

Samples tubes were then subsequently analysed with a Perkin Elmer automated thermal desorber ATD 400 coupled with a gas chromatograph equipped with a flame ionisation detector (FID). Analytical conditions are given in Table 3 .

For this sampling time (10 hours) and flow rate $\left(10 \mathrm{~mL} \mathrm{~min}^{-1}\right)$, the quantification limit of this method is $4 \mu \mathrm{g} \mathrm{m}^{-3}$ of tetrachloroethylene. The uncertainty associated to this measurement is estimated to $30 \%$.

\section{Sampling and analysis with passive tubes}

Silent and not cumbersome, this very convenient technique for indoor air measurements allows time-integrated concentrations over long sampling periods. A key factor when performing measurements with passive samplers is the steadiness of the uptake rate over the sampling period. The performance of a radial sampler consisting of the combination of an empty Perkin Elmer tube fitted with a $4.8 \mathrm{~mm}$ od Radiello cartridge containing $150 \mathrm{mg}$ Carbotrap B obtained from the Fondazione Salvatore Maugeri (Radiello Perkin-Elmer sampler) and a radial passive sampler (Radiello model 145) was evaluated in a 150 L Pyrex exposure chamber under controlled conditions of temperature, relative humidity and wind speed. A full description of the exposure chamber is given in Gonzalez-Flesca and Frezier, 2005. The chamber operating conditions were $20^{\circ} \mathrm{C}, 50 \%$ relative humidity, $1 \mathrm{~m} \mathrm{~s}^{-1}$ wind speed and the VOCs concentrations were $85 \mu \mathrm{g} \mathrm{m}^{-3}$ of benzene, $132 \mu \mathrm{g} \mathrm{m}^{-3}$ of trichloroethylene, $180 \mu \mathrm{g} \mathrm{m}^{-3}$ of toluene and $127 \mu \mathrm{g} \mathrm{m}^{-3}$ of tetrachloroethylene. As schematic of the tubes is given on Figure 1. 
The uptake rate steadiness for both samplers, Radiello 145 filled with carbograph 4 used with the yellow diffusion membrane (polyethylene $5 \mathrm{~mm}$ thick, $10 \pm 2 \mu \mathrm{m}$ porosity, $150 \mathrm{~mm}$ diffusive path length), and Radiello-Perkin-Elmer (also filled with carbograph 4) and several compounds (benzene, toluene, trichloroethylene and tetrachloroethylene) as a function of sampling time is presented in Figure 2. It can be observed that the axial Radiello Perkin-Elmer sampler provides a lower but steadier uptake rate than the radial sampler. The sampling flow rate for PCE has then been determined equal to $0.3 \mathrm{~mL} \mathrm{~min}^{-1}$.

No experience has been carried out in the chamber at high PCE concentrations (about a few $\left.\mathrm{mg} \mathrm{m}^{-3}\right)$ to estimate the tube limit of linearity range. However, some field experiments in a dry cleaning facility involving active sampling on tubes filled with Carbopack X (CPX) adsorbent and Radiello-Perkin-Elmer passive tubes have been performed. Passive samplers have been exposed during 7 days while several samplings, 9 series of 2 samplings covering the 7 days passive tube exposure, have been performed. Both methods gave the same results $(93 \mathrm{mg} \mathrm{m}-3$ has been measured by active sampling while $97 \mathrm{mg} \mathrm{m}^{-3}$ has been measured by passive sampling). It can thus be concluded that Radiello-Perkin-Elmer tubes can be used for sampling in high concentration PCE atmosphere.

This sampler was therefore chosen for field measurement campaigns.

Samples were thermodesorbed by an ATD 400 Perkin-Elmer thermodesorber, pre-concentrated on a cold trap (Turbomatrix Perkin Elmer pre-concentrator) and analysed by GC-FID (Autosystem XL Perkin Elmer equipped with a capillary column PLOT Alumine / KCl)

For this sapling time (7 days) and flow rate $\left(0.3 \mathrm{~mL} \mathrm{~min}^{-1}\right)$, the quantification limit of this method is $0.1 \mu \mathrm{g} \mathrm{m}^{-3}$. The uncertainty associated to these passive tube measurements is estimated to $30 \%$ (the uncertainty was determined on the bases of 3 chamber experiments performed in the same conditions as discribed before and on the bases of the comparison between active sampling as reference method and Radiello-Perkin-Elmer passive sampling during the field experiment described above).

\section{Calibration and quantification}

Quantification was performed by using PCE liquid solutions. $1 \mu \mathrm{L}$ of each standard solution were evaporated on Radiello-Perkin-Elmer tubes with a Dynatherm tube conditioner Model 60 (Supelco). PCE vaporised mass were ranging from 3 to $130 \mu \mathrm{g}$ corresponding to 0.9 to $45 \mathrm{mg} \mathrm{m}^{-3}$ As for measurement of lower PCE concentrations (about a few $\mu \mathrm{g} \mathrm{m}^{-3}$ ), quantification was performed by on-line injection of hydrocarbon gas standards $(50 \mathrm{ppb})$ mixture from Air Liquid (CARBAGAS, Switzerland).

\section{Results and discussion}

A summary of the results obtained during the five studies is presented in Table 4. Standard deviation is given for each measurement except for studies 1 and 2 since only one canister sampling has been made at each sampling point. Also, only one measurement has been made on the building floors during study 4. Lets remind that the measurement uncertainty including sampling and analysis is estimated to $30 \%$.

\section{Tetrachloroethylene concentrations in the shopping centre (Study 1)}

The highest tetrachloroethylene concentration is naturally measured in front of the dry cleaning shop $\left(678 \mu \mathrm{g} \mathrm{m}^{3}\right)$. Relatively high concentrations can still be measured at the sampling points far away ( the furthest sampling point is about $60 \mathrm{~m}$ away from the dry cleaning facility) from the emission source $\left(50 \mu \mathrm{g} \mathrm{m}^{3}\right.$ at the back of the supermarket).

Figure 3 presents an isoconcentration plot calculated with Surfer (Scientific Software Group) in order to estimate the concentration profile in the supermarket. Despite the use of a machine equipped with a CA, the fugitive emission of PCE is not negligible. A suitable AES is recommended to further reduce the emission of PCE and thus the exposure inside the shopping 
mall. Indoor air concentrations in shopping mall housing dry cleaning facilities is not documented. Concentrations levels measured in this study should encourage further research.

Tetrachloroethylene concentrations in the dry cleaning shops (Studies 2-5)

Several measurements were carried out in each dry cleaning facility (at least 3 samples per shop). The tetrachloroethylene arithmetic mean levels are reported in Table 4.

Except study 2 (low dry cleaning activity, special sampling period and technique), studies 3-5 concentrations ranges indicate rather low levels of PCE in dry cleaning shops (8 to $53 \mathrm{mg} \mathrm{m}^{-3}$ ) compared with occupational literature data. Occupational mean concentrations levels of $69 \mathrm{mg} \mathrm{m}^{-3}(10 \mathrm{ppm})$ were reported by Poirot et al., 2007 in a 3 dry cleaners study.

In studies 3 and 4, PCE mean concentration levels are similar considering measurement uncertainties (32 \pm 10 and $53 \pm 16$ respectively). However, PCE concentrations measured in study 4 are slightly higher than concentrations measured in study 3 , which could be explained by the higher temperature in study $4\left(26.9^{\circ} \mathrm{C}\right.$ in the dry cleaner and 26.9 in the apartments) than in study $3\left(19.2^{\circ} \mathrm{C}\right.$ in the dry cleaner and 18 in the apartments).

Both of them were in the same configuration: no AES, CA unequipped machine, normal activity. However, significant decrease of tetrachloroethylene concentrations in dry cleaning facilities operating with a CA equipped machine (study 5) in comparison to an unequipped machine (study 3 and 4) can be observed even if other contributing parameters (machine life span, machine maintenance and PCE consumption) have not been assessed. These results enlighten the positive influence of a CA and an AES on indoor air quality.

It can be noticed that measured concentrations in study 2 also carried out in a dry cleaner involving an unequipped machine are comparable to concentrations measured in study 5 ( $4^{\text {th }}$ generation machine). This could be explained by the dry cleaning facility activity during the sampling period which was low in the case of study 2 and normal in the case of study 5 . These two studies are difficult to compare since the sampling periods were different, only 10 hours in the case of study 2 and a whole week in the case of study 5. Samples in study 2 were not as representative of population exposure as samples in study 5 and may have not been taken when PCE concentrations in the dry cleaner were the highest.

Besides, it should be noted that dry cleaners PCE levels measured in this study were far below the $335 \mathrm{mg} \mathrm{m}^{-3}$ exposure limit value required by the French occupational health regulation.

\section{Tetrachloroethylene concentrations in the residential buildings (Study 2-5)}

The concentration ranges measured in the apartments and on the floors from the bottom up to the top of the buildings are reported in Table 4. A decrease of PCE concentrations with floor levels can be observed as shown on Figure 4 and Figure 5. Mean concentrations are represented on each figure with standard deviation which is about $5 \%$ (ranging from 1.5 to $6.4 \%$ ) for floors measurements and $10 \%$ (ranging from 1 to $12 \%$ ) for apartment measurements. Mean values, 5 and $10 \%$ are taken for graphic representation. The lower floor standard deviation can be explained by the fact that replicates measurements on the floor are taken exactly at the same location whereas in the apartments some sampling are made in different places.

Comparing concentrations measured inside the apartments and on the building floors, it appears that, in each case (studies 3-5), concentrations are greater on the floors than inside except for level 1 which shows concentrations 20 to $50 \%$ greater inside than on the floors. This could be explained by the fact that level 1 , located directly above the dry cleaning facility, is the level under the greatest PCE influence and that accumulation phenomena are more important in apartments than in the staircase. 
Significant lower indoor air levels in both apartments and dry cleaners can be observed in study 5 (CA equipped machine) in comparison with studies 3 and 4 (CA unequipped machine). Indeed, mean concentrations measured in the apartment located directly above the dry cleaning facility ranged from $296 \mu \mathrm{g} \mathrm{m}^{-3}$ in the case of a CA equipped machine to $2.9 \mathrm{mg} \mathrm{m}^{-3}$ in the case of an unequipped machine. This reduction could be attributed to the combined action of the CA and the AES. Residential indoor air levels found in dry cleaner buildings with type unequipped machines are consistent with published value. Indoor air concentrations up to $5.5 \mathrm{mg} \cdot \mathrm{m}^{3}$ were reported in Germany, New Jersey and New-York respectively by Altmann et al., 1995; Garetano and Gochfeld, 2000; Schreiber et al., 2002. In all cases (studies 2 to 5), these values are higher than the mean PCE concentrations $7.4 \mu \mathrm{g} \mathrm{m}^{-3}$ measured in the dwellings of 567 French families between 2003 and 2005 (Observatory on Indoor Air Quality (OQAI), 2006).

\section{Discussion: measurement uncertainties}

The reduction of PCE concentrations noted in study 5 can be attributed to the use of a carbon adsorber and mechanical ventilation.

Nevertheless, it must be pointed out that indoor air PCE levels can depend on several other parameters that have not been quantified in this study such as the air renewal rate not only of the dry cleaning facility but also the apartment located above, the residents life habits (smoking habit, ventilation...) which have only been evaluated by a simple questionnaire given to the residents, the building structural conditions (e.g. insulation, poorly sealed pipe chases or crack in the wall) the amount of solvent used,... all these factors should be taken into account for a full understanding of PCE fugitive release process in dry cleaner buildings.

\section{Conclusion}

These five exploratory studies have shown the degradation of indoor air quality in one shopping mall and four residential buildings housing a dry cleaning facility.

Tetrachloroethylene concentrations in residences in the same building were found to decrease with floor levels.

The results have underlined the contributing role of the dry cleaning machine technology and ventilation on the amount of tetrachloroethylene fugitive emissions. Among the 4 dry cleaner building studied, the lowest indoor air levels were measured in the residential building with onsite dry cleaners equipped with a CA fitted machine and a mechanical air exhaust system. For the three other dry cleaner buildings equipped with CA unfitted machines, two of them had indoor air concentrations at all floor levels (5 and 7 floors buildings) all above $1 \mathrm{mg} \mathrm{\textrm {m } ^ { 3 }}$. Such concentrations levels are much higher than the health-based guideline of $100 \mu \mathrm{g} \mathrm{m}^{-3}$ (15 ppb) recommended by the New York State Department of Health (NYSDOH).

Although this study was performed on a limited number of dry cleaning establishments, the finding confirmed that indoor air concentrations in some residential dry cleaner buildings are of public health concern and that measures should be taken to reduce the exposure. Efficient ventilation and the use of CA fitted machine tend to minimise the exposure of the occupant in building with on-site dry cleaners. However, it should be pointed out that the impact of each factor has not been quantified separately. In addition, other potential important parameters such as building insulation or maintenance practice on the amount of PCE available for diffusion through the building have not been quantified at all.

Further investigation is needed to identify factors affecting PCE concentrations in order to take appropriate measures to reduce the exposure of dry cleaner building residents.

A population risk exposure based the result from this study will be presented in a separate article. This is a first French study on the population exposure to dry cleaning tetrachloroethylene as a function of machine technology. Supported by the French Ministry of Environment, this study 
has important insight into the issue concerning the possibly harmful health effects of the population indoor exposure to tetrachloroethylene.

\section{Acknowledgement}

The authors would like to thank the French Ministry of the Environment which have supported this work 


\section{References}

Altmann, L., H. F. Neuhann, U. Kramer, J. Witten, and E. Jemman (1995) "Neurobihavioural and neurophysiological outcome of chronic low-level tretrachloroethylene exposure measured in neighborhoods of dry cleaning shops", Environmental Research, 69, 83-89.

Castellnou, A., N. Gonzalez-Flesca, and J. O. Grimalt (1997) "Refrigerated multibed adsorption in sampling and analysis of atmospheric light hydrocarbons at ppb (v/v) and sub-ppb (v/v) concentrations", Journal of chromatography A, 778, 269-277.

Delery, L. (2007) "Etude du parc français des installations de nettoyage à sec suite à la mise en œuvre de l'arrêtétype 2345 (2 mai 2002)", INERIS DRC-07-86835-11993A pour le ministère de l'Ecologie, du Développement et de l'Aménagement durables,

Garetano, G., and M. Gochfeld (2000) "Factors influencing tetrachloroethylene concentrations in residences above dry-cleaning establishments", Environmental Health, 55, 59-68.

Gonzalez-Flesca, N., and A. Frezier (2005) "A new laboratory test chamber for the determination of diffusive sampler uptake rates", Atmospheric Environment, 39, 4049-4056.

NYSDOH (1997) Tetrachloroethylene Ambient Air Criteria Document, Albany, N.Y.: New York Sate Department Of Health,

Observatory on Indoor Air Quality (OQAI) (2006) National survey: indoor air quality in French dwellings,

Poirot, P., M. T. Leclerc, B. Galland, G. Hubert-Pelle, T. Nicot, and J. Grosjean (2007) "Profils d'exposition au perchloroéthylène dans le secteur du nettoyage à sec, Hygiène et sécurité du travail, cahiers de notes documentaires", INRS - Hygiène et sécurité du travail - cahiers de notes documentaires, 209, 45-60.

Schleibinger, H., U. Hott, P. Braun, D. March, and H. Rueden, 2003, Recommandations for establishing target values and guidance values for volatile organic compounds (VOC) in indoor air: Healthy Buildings 2003 - Proceedings 7th International Conference, p. 586-592.

Schreiber, J. S., H. K. Hudnell, A. M. Geller, D. E. House, K. M. Aldous, M. S. Force, K. Langguth, E. J. Prohonic, and J. C. Parker (2002) "Apartment Residents and day care workers exposures to tetrachloroethylene and deficits in visual contrast sensitivity", Environmental Health Perspectives, 110 655-664.

USEPA (2000) Tetrachloroethylene Hazard Summery, 


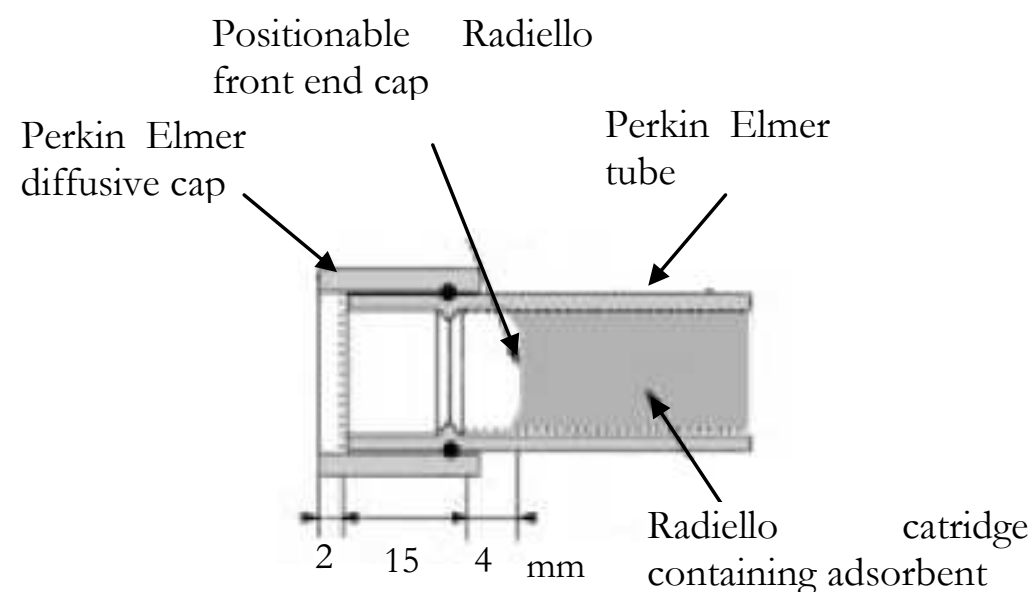

Figure 1: Schematic of the Radiello Perkin Elmer configuration (Gonzalez-Flesca and Frézier, 2005) 


\section{Radiello uptake rate}

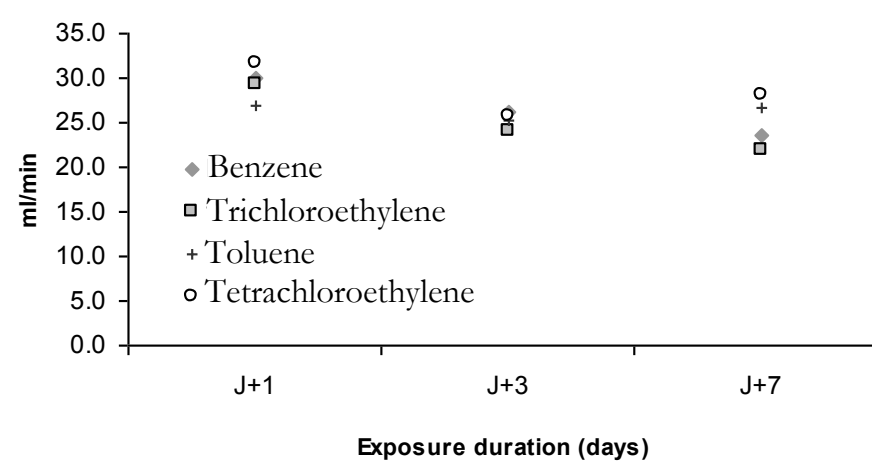

Radiello Perkin Elmer uptake rate

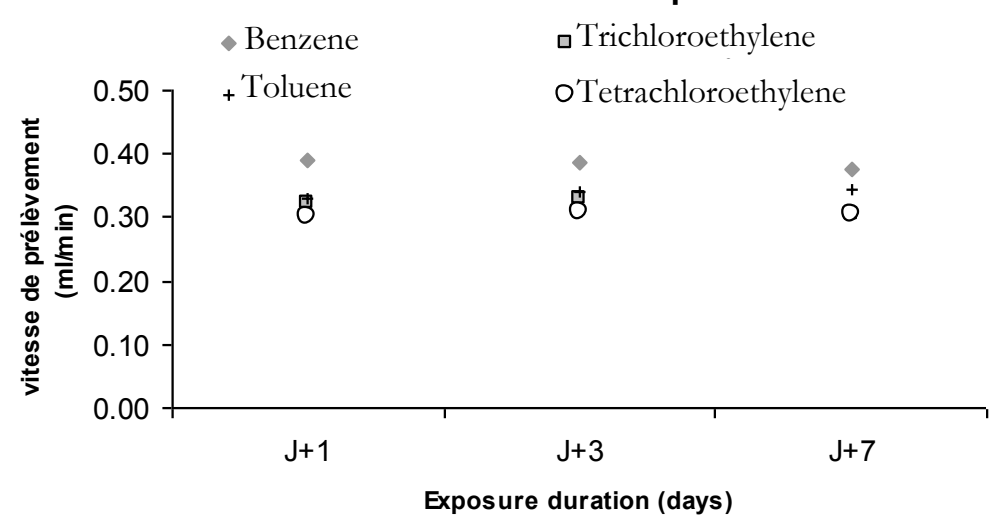

Figure 2 : Uptake rate of Radiello and Radiello-Perkin-Elmer samplers as a function of exposure duration (this work). 


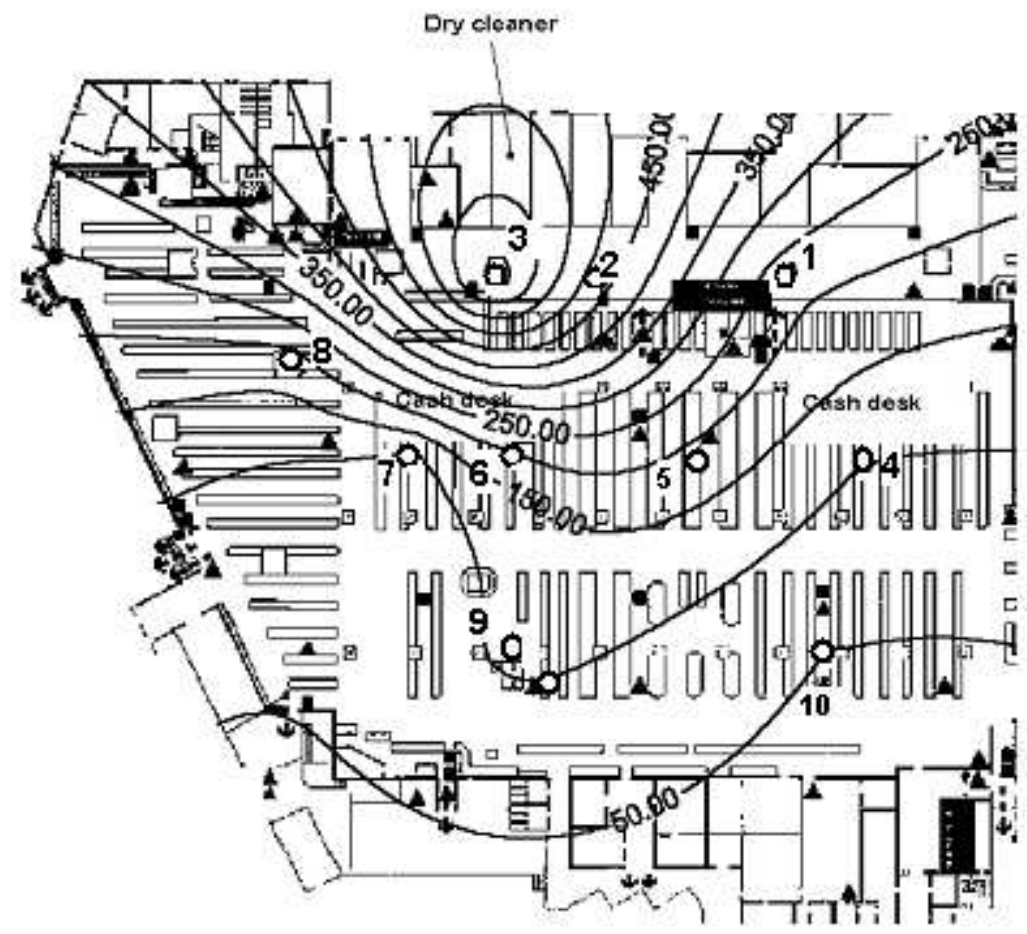

Figure 3 : Sampling sites and isoconcentration plots (study 1). The distance between the dry cleaner and the furthest sampling point (10) is around $60 \mathrm{~m}$. 


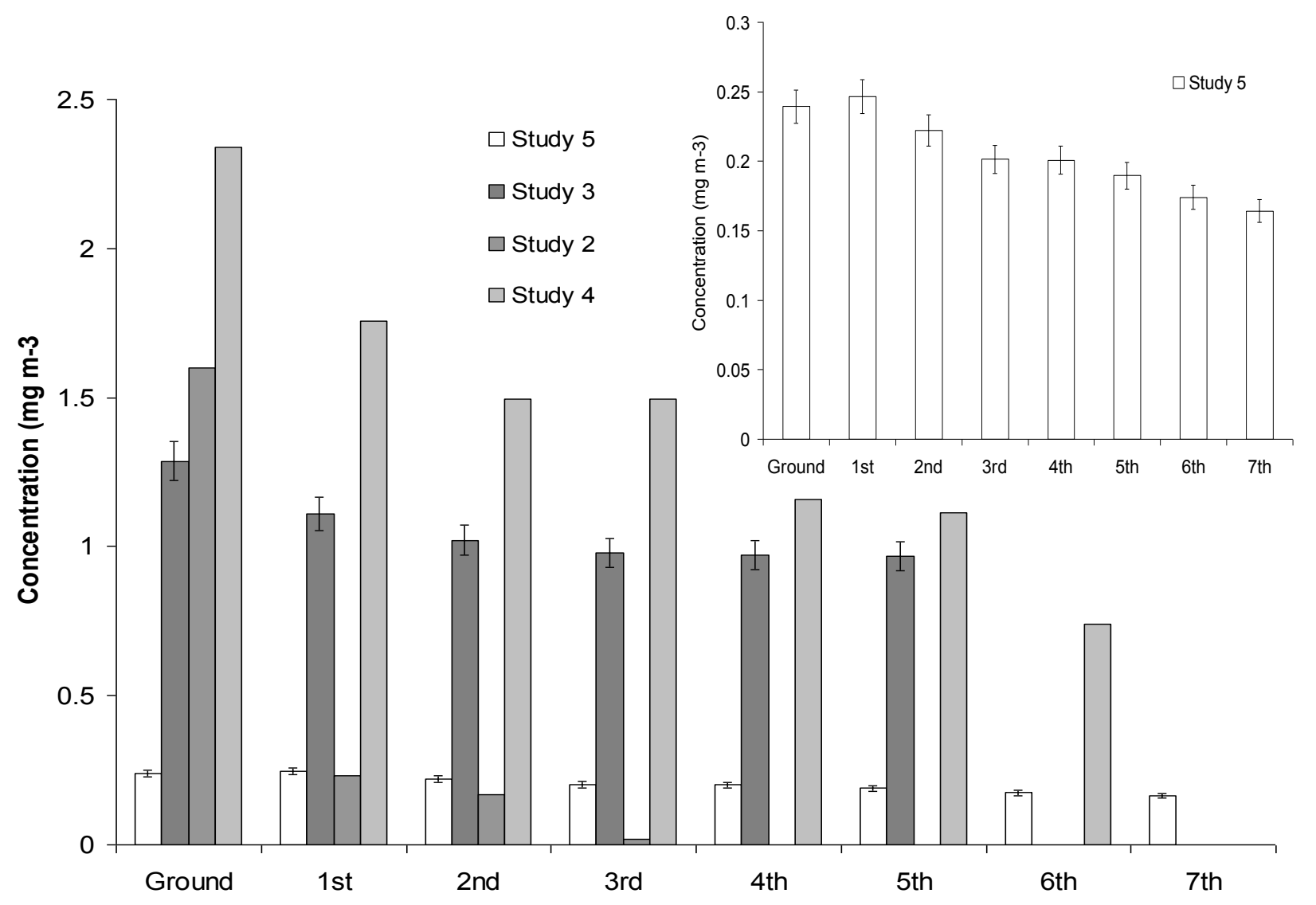

Figure 4: Concentrations measured on the floors from bottom to top of the residential buildings (studies 2 to 5). Standard deviation for passive tube measurements (studies 3-5) are given (no standard deviation is given for studies 2 and 4 since 1 sample per location has been taken). 


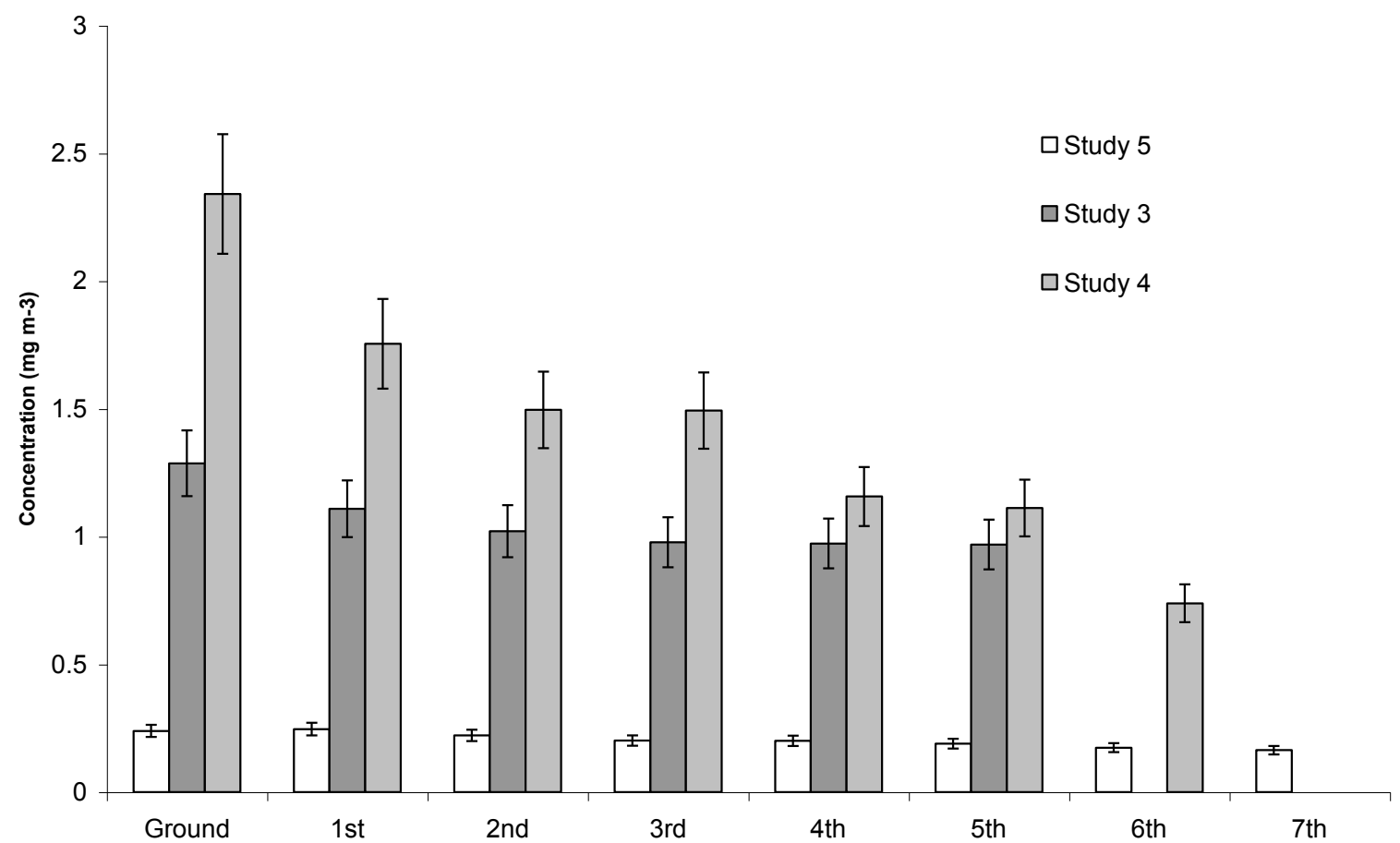

Figure 5 : Concentrations measured in the apartments from bottom to top of the residential buildings (studies 3 to 5). Standard deviation are given. 
-14 - 
Table 1 : Sampling sites description (machine type: $\mathrm{CA}=$ closed cry cleaning machine with refrigeration cooling and carbon adsorber, No $\mathrm{CA}=$ closed cry cleaning machine with refrigeration cooling without exhaust air $\quad *$ normal $=6-8$ loads $/$ day)

\begin{tabular}{|c|c|c|c|c|c|c|c|}
\hline Study & Year & $\begin{array}{l}\text { Dry } \\
\text { cleaning } \\
\text { shop } \\
\text { location }\end{array}$ & $\begin{array}{c}\text { Machine } \\
\text { Type }\end{array}$ & $\begin{array}{c}\text { Dry } \\
\text { cleaning } \\
\text { shop } \\
\text { ventilation }\end{array}$ & $\begin{array}{c}\text { Dry } \\
\text { cleaning } \\
\text { facility } \\
\text { activity* }\end{array}$ & Sampling location & $\begin{array}{c}\text { Mean } \\
\text { temperature } \\
{ }^{\circ} \mathrm{C}\end{array}$ \\
\hline Study 1 & 2002 & $\begin{array}{l}\text { Shopping } \\
\text { mall }\end{array}$ & CA & No & High & $\begin{array}{c}9 \text { sampling sites in the } \\
\text { supermarket }\end{array}$ & Not available \\
\hline Study 2 & 2002 & $\begin{array}{l}\text { Building } \\
\text { with on- } \\
\text { site dry- } \\
\text { cleaner }\end{array}$ & No CA & No & Low & $\begin{array}{l}4 \text { in the dry cleaning } \\
\text { facility } \\
1 \text { from the } 1^{\text {st }} \text { to the } \\
4^{\text {th }} \text { staircase floor in } \\
\text { the staircase } \\
1 \text { outside }\end{array}$ & Not available \\
\hline Study 3 & 2005 & $\begin{array}{l}\text { Building } \\
\text { with on- } \\
\text { site dry- } \\
\text { cleaner }\end{array}$ & No CA & No & Normal & $\begin{array}{l}4 \text { in the dry cleaning } \\
\text { facility } \\
-2 \text { in the staircase } \\
\text { and } 2 \text { in apartments } \\
\text { above (from the } \\
\text { ground to the } 6^{\text {th }} \\
\text { floor) at each floor }\end{array}$ & $\begin{array}{l}\text { Dry Cleaning } \\
\text { facility: } 19.2 \\
\text { Apartments: } 18\end{array}$ \\
\hline Study 4 & 2005 & $\begin{array}{l}\text { Building } \\
\text { with on- } \\
\text { site dry- } \\
\text { cleaner }\end{array}$ & No CA & No & Normal & $\begin{array}{c}4 \text { in the dry cleaning } \\
\text { facility } \\
1 \text { in the staircase and } \\
2 \text { to } 3 \text { in apartments } \\
\text { above (from the } \\
\text { ground to the } 6^{\text {th }} \\
\text { floor) at each floor }\end{array}$ & $\begin{array}{l}\text { Dry Cleaning } \\
\text { facility: } 26.9 \\
\\
\text { Apartments: } \\
29.1\end{array}$ \\
\hline Study 5 & 2007 & $\begin{array}{l}\text { Building } \\
\text { with on- } \\
\text { site dry- } \\
\text { cleaner }\end{array}$ & CA & Yes & Normal & $\begin{array}{l}3 \text { in the dry cleaning } \\
\text { facility } \\
1 \text { in an adjacent shop } \\
2 \text { in the staircase and } \\
2 \text { in apartments above } \\
\text { (from the ground to } \\
\text { the } 7^{7 \mathrm{~h}} \text { floor) at each } \\
\text { floor }\end{array}$ & $\begin{array}{l}\text { Dry Cleaning } \\
\text { facility: } 20.3 \\
\text { Apartments: } \\
20.4\end{array}$ \\
\hline
\end{tabular}


Table 2: Sampling device and period $(n=$ number of samplings)

\begin{tabular}{c|c|c} 
Study & Sampling device & Sampling period \\
\hline Study $\mathbf{1}$ & 6 L Stainless steal canister (n=9) & $\begin{array}{c}10 \text { hours } \\
\text { (from 9 am to 7 pm, June 2002) }\end{array}$ \\
\hline Study $\mathbf{2}$ & 6 L Stainless steal canister ( $\mathrm{n}=9)$ & $\begin{array}{c}10 \text { hours } \\
\text { (from 9h30 am to 6h30 pm, July 2002) }\end{array}$ \\
\hline Study $\mathbf{3}$ & Passive sampling $(\mathrm{n}=32)$ & $\begin{array}{c}7 \text { days } \\
\text { (April 2005) }\end{array}$ \\
\hline Study $\mathbf{4}$ & Passive sampling $(\mathrm{n}=43)$ & $\begin{array}{c}7 \text { days } \\
\text { (June 2005) }\end{array}$ \\
\hline Study $\mathbf{5}$ & Passive sampling $(\mathrm{n}=38)$ & $\begin{array}{c}7 \text { days } \\
\text { (March 2007) }\end{array}$
\end{tabular}


Table 3 : Passive tubes analytical conditions

\begin{tabular}{c|c} 
ATD 400 & Gas chromatograph \\
\hline Cold trap: Carbopack B + Carbosieve SIII & Carrier gas: He at $2 \mathrm{ml}^{-m_{i}{ }^{-1}}$ \\
\hline Desorption temperature: $\mathbf{3 5 0} \mathbf{C}$ & capillary column PLOT Alumine $/ \mathrm{KCl}$ \\
\hline Desorption time: $\mathbf{1 0 ~} \mathrm{min}$ & Column temperature program: $45^{\circ} \mathrm{C}(10 \mathrm{~min})-$ \\
& $170\left(7.5^{\circ} \mathrm{C} \mathrm{min}^{-1}\right)-200\left(15^{\circ} \mathrm{C} \mathrm{min}^{-1}, 6.5 \mathrm{~min}\right)$ \\
\hline Trap temperature: - 30 C & Detector: FID at $250^{\circ} \mathrm{C}$
\end{tabular}


Table 4 : Summary of PCE concentrations $\left(\mathrm{mg} \mathrm{m}^{-3}\right)$ for each study (from 1 to 5 ). Standard deviation for passive tube measurements (studies 3-5) are given. No standard deviation is given for Studies 1 and 2 and on the buildings floor of study 4 since 1 sample per location have been taken.

\begin{tabular}{|c|c|c|c|c|}
\hline Study & $\begin{array}{l}\text { Mean in dry } \\
\text { cleaning shop }\end{array}$ & Range in shopping centre & $\begin{array}{l}\text { Range in } \\
\text { residential } \\
\text { building } \\
\text { apartments }\end{array}$ & $\begin{array}{l}\text { Range on the } \\
\text { residential } \\
\text { building floors }\end{array}$ \\
\hline $\begin{array}{l}\text { Study } 1 \\
\text { (CA fitted } \\
\text { machine) } \\
\end{array}$ & - & $\begin{array}{l}0.050(\sim 110 \mathrm{~m} \text { away from } \\
\text { the dry cleaner- } 0.67(20 \mathrm{~m} \\
\text { away from the dry cleaner })\end{array}$ & - & - \\
\hline $\begin{array}{c}\text { Study } 2 \\
\text { (CA unfitted } \\
\text { machine) }\end{array}$ & 11 & - & - & $\begin{aligned} 0.020 & \left.4^{\text {th }} \text { floor }\right)- \\
1.6 & \left(1^{\text {st }} \text { floor }\right)\end{aligned}$ \\
\hline $\begin{array}{c}\text { Study } 3 \\
\text { (CA unfitted } \\
\text { machine) } \\
\end{array}$ & $32 \pm 12$ & - & $\begin{array}{c}0.10 \pm 0.01\left(5^{\text {th }}\right. \\
\text { floor })-2.2 \pm 0.5 \\
\left(1^{\text {st }} \text { floor }\right)\end{array}$ & $\begin{array}{c}0.97 \pm 0.01\left(5^{\text {th }}\right. \\
\text { floor })-1.3 \pm 0.05 \\
\text { (ground) } \\
\end{array}$ \\
\hline $\begin{array}{c}\text { Study } 4 \\
\text { (CA unfitted } \\
\text { machine) }\end{array}$ & $53 \pm 10$ & - & $\begin{array}{c}0.23 \pm 0.04\left(5^{\text {th }}\right. \\
\text { floor })-2.9 \pm 0.3 \\
\quad\left(1^{\text {st }} \text { floor }\right)\end{array}$ & $\begin{array}{c}\left.0.74 \text { ( } 6^{\text {th }} \text { floor }\right)- \\
2.3 \text { (ground })\end{array}$ \\
\hline $\begin{array}{l}\text { Study } 5 \\
\text { (CA fitted } \\
\text { machine) }\end{array}$ & $8 \pm 2$ & - & $\begin{array}{l}0.103 \pm 0.004\left(7^{\text {th }}\right. \\
\text { floor })- \\
0.296 \pm 0.032\left(1^{\text {st }}\right. \\
\text { floor })\end{array}$ & $\begin{array}{c}0.164 \pm 0.002\left(7^{\text {th }}\right. \\
\text { floor })- \\
0.246 \pm 0.001\left(1^{\text {st }}\right. \\
\text { floor })\end{array}$ \\
\hline
\end{tabular}


